\title{
Effect of Capital Gains Tax on Economic Growth and Development in Nigeria (2011-2016)
}

\author{
Omesi, Israel Ph.D \\ Department of Accounting, Faculty of Business Studies \\ Ignatius Ajuru University of Education, Rumuolumeni, Port Harcourt, Rivers State \\ Akpeekon, Barisua \\ Department of Accounting, Faculty of Business Studies \\ Ignatius Ajuru University of Education, Rumuolumeni, Port Harcourt, Rivers State
}

\begin{abstract}
The study empirically examined the effect of capital gains tax on the economic development in Nigeria from 2011 - 2016. Data for the study was obtained mainly from secondary sources, the statistical data based and Bulletin of the Central Bank of Nigeria (CBN) and the website of the Federal Inland Revenue Services (FIRS). Simple regression was employed in determining the functional relationships existing between the variables in the model. Ordinary least square (OLS) method was used to compute the formulated hypotheses. The result showed that capital gains tax contributes significantly to the total tax revenue of government and by extension the economic development of Nigeria. It is therefore recommended that government should be transparently and use revenue generated through capital gains tax for the development of the economy, as tax payers would be willing to pay. The government on the other hand should be able to develop the economy to justify the collection of tax payers money.
\end{abstract}

Keywords:Capital gains tax, economic growth and development, revenue generated and tax payers, money.

DOI: $10.7176 /$ RJFA/10-17-04

Publication date:September $30^{\text {th }} 2019$

\section{Introduction}

Generating revenue through tax is one serious business of the government all over the world today. Tax driving remains one of the must-do-function and critical responsibility of government at all levels of governance in order to raise enough revenue and develop the economy. But in doing so, government must recognize the type of taxes and their tax driving mechanism to avoid non-compliance. Taxes paid to the government include personal income tax, company income tax, petroleum profit tax, value added tax and of course, capital gains tax. All these taxes generate revenue to the government through one way or the other. Taxes are used to achieve economic growth, equity in income and wealth creation as well as distribution (Gatawa, Aliero and Aishatu, 2016). It also helps in balancing and maintaining equilibrium in the economy as well as re-distribution of income in the economy, to mention but a few.

Thus, the issue of capital gain tax in Nigeria appears to be gaining more popularities as government has now reviewing the tax position as a component of the subsisting fiscal policy for the purpose of meeting government needs.

Mondugu and Anyandubaa (2014) opined that one of the primary objectives and purpose of raising taxes is essentially to carry out legitimate duties of government. Legitimacy comes in when it is used for economic development which is the constitutional duty of the government. Thus, the importance of raising taxes lies within the ability to raise capital formation for the economic growth and development as well as assisting in the regulation of consumption pattern which will be much more later result to economic stabilization and effective redistribution of income (ICAN, 2009). A vibrant tax system such as capital gains tax required by the government at all levels to be proactive in tax revenue to drive home these processes. Elleman and Obaro (2011) identified different kinds of tax enforcement strategy capable of inducing compliance as aggressive tax drive campaign by relevant complying units to meet non-complying companies to convince their decisions to effect tax payments.

In Nigeria capital gains tax are paid by corporate organizations or companies through and effective capital gains tax administration. An effective capital gain tax administration is one that ensure a smooth running operation of the tax operation and ensure that each company operating in a locality or state pays taxes to the government as at when due through their various tax offices.

Tax compliance therefore, depends on the sincerity and honest of the tax operators to remit whatever money paid by the companies through to their different state offices and the ability to give adequate and accurate information about their gains or income (FBIR, 2010). Thus, if the tax operators are honest and committed to their jobs, duties or responsibilities the economy may be far driving and government objectives such economic development can be achieved in no distance time. Economic growth and development will bounce back 
immediately taxes are paid and the operators are sincere and committed to the ideals of their work. All these can be gained through an effective and efficient capital tax administration. The administration of tax laws is directly under the supervisor and management of the Federal Inland Revenue Board to provide certain provisions of the income tax Acts and detailed schedule as per how capital gains tax Acts is to be chargeable under the Act. Gains arising from increases in the market value of capital assets is another important component of capital gains to the government. Capital gain taxes raises revenue for the government but does that in consideration of economic costs. Capital gains are taxed on a realization basis. The implication is that the tax is only imposed when investors decide to withdraw their investment from the market, thus capital gain realized. One of the important aspects of capital gains is the incentive this creates for the carriers of capital to retain their current investments even though more profitable and production opportunities are available, (Igweike, 2003).

The non-compliance with capital gains tax payment by firms possess great danger to the development of the economy thereby perpetuating inequalities in income and wealth as capital gains only accrues to those companies. Non payments of capital gains tax accruing especially to those within the higher income bracket puts more relative pressure or burden on the income tax who do not enjoy such gains (Ayua, 1999). Developing countries like Nigeria stands a better chance to gain a lot from capital gains tax for the purpose of developing its economy because of the tendency of raising prices inevitably, company profits and value of shares (Olong, 2006). Thus, a lots have been argued in different accounting literatures of the effects of capital gains tax on the economy of any country, not much have been done to ascertain the reality in the concepts. This paper seeks to empirically investigate the effect capital gains tax on the economy development of Nigeria.

Generating revenue through taxes, more-especially through capital gain tax is one key function of the government to developed, enhance economic development and to better the life of its citizenry. Taxes are used to achieve economic growth, equity in income and wealth creation as well as distribution (Gatawa, Aliero and Aishata, 2016). Thus, this idea was defeated because of lack of transparency, accountability on the part of the administrators and the issue of non-compliance with the payments and other tax related matters give a wrong and negative signals. Economic growth and development suffers serious setbacks and stagnated. Economic recession at this point becomes the experiences of a common man. Government can no longer carry out its policies and programmes effectively. There has been persistent falls or drops in government revenue, hence economic growth and development becomes stagnated.

\section{Objective of the Study}

From the foregoing, the paper seeks to:

1. Examine the effect of capital gains tax on the economy development in Nigeria.

2 Ascertain the extent to which capital gain tax improve the compliance to achieve economy development in Nigeria.

\section{Research Questions}

This work attempted to answer the following question

1. To what extent does capital gains for affect the economy development in Nigeria within the period under review?

2. To what extent does capital gains tax improve the compliance to achieve economy development in Nigeria?

\section{Research Hypotheses}

To enable the research achieve the objectives of the study, the following research questions were hypothesised.

$\mathrm{Ho}_{\mathrm{i}}$ : $\quad$ There is no relationship between capital gains tax and the economy development in Nigeria.

$\mathrm{Ho}_{\mathrm{ii}} \quad$ Capital gains tax has no effect on the economy development of Nigeria within the period under review.

\section{Related Literature Review - Conceptual Framework \\ Capital Gains Tax}

Capital gains tax is the income derived from the sales of a capital asset. They are at most cases tax payable on stocks, shares, securities, land, buildings, plant and machinery and even goodwill from business. Assessing the economic development of a country, capital gain tax increases a person's taxable capacity by way of increasing his power to spend or save. Capital gains tax is usually profits or losses or disposal of fixed assets. (ICAN, 2009). Adeyemi \& Babinglin (2001) opined that the government obligations to developed the economy and made provision of certain basic amenities for its citizens. To do this, government must intensify on other taxes and taxes on disposal of non-current assets. This will go a long way developing the economy. Developing economy gains much more from capital gains tax (Tripathy, 1978). It is a very lucrative ground for generating revenue for the purposes of developing the economy. Oserogho, (2004) posited that the principal problem that affects capital gains tax is the problem of lack of data or record for tax authorities to be aware of when capital gains have been 
made and payment made accordingly.

\section{Economic Growth and Development}

Economic growth is the increase in a country's physical output over a long period of time. Adams (2009) stated that economic growth is when the real output of goods and services is increasing at a faster rate than the rate of growth of it's population. Thus, a country economic growth is determine by the rate of physical output of goods and services over a reasonable period of time with an improve standard of living. Economic development on the other hand is the elimination or reduction in poverty, inequality and unemployment within the context of a growing economy.

Ogbonna and Appah (2012), opined that economic growth is a sustained increased in per capital national output or net national produce over a period of time. The implication is that the rate of increase in total output must be greater than the rate of input. Leonidal et al (2008) studied tax planning and international financial reporting standards IFRS, the research employed descriptive statistics. The result of the finding showed that firms use deferred tax strategy in order to reduce future tax expenses; meet their tax planning policies thereby reducing tax revenue accruable to government.

Beeson et al, (2016) examined the determinants of income tax compliance in Maurithius for tax payers. The study adopted primary survey design to obtain data which was analyzed with the aid of thematic statistical analysis. Their study result suggests that knowledge about tax payment impact significantly on tax compliance and that statutory audit, penalties personal finance constraints perceptions of government expenditure influence compliance level.

\section{Theoretical Review}

The paper is anchored on the benefit received theory and cost of service theory.

i. $\quad$ Benefits received theory. This theory is also called vertical equity stipulates that an individual ought to be taxed according to the benefits he receives from government for the provision of goods and services. This is in line with the benefit cost approach in which tax is a cost and government amenities are the benefits. This theory assumes a state of equality between marginal tax rate (MTR) and marginal benefit received (MBR) to determine the amount of taxes paid. Thus, capital gain tax accrues so many benefits for the development of the economy, hence, the theory is in line with the research work.

ii. Cost of service theory: This is another theory that is in favour of this study. The theory state that there is a semi-commercial relationship that exist between the state and, the tax payers. The theory stipulates that the state should give basic protective, incentives and welfare services to the citizenry in consideration of the cost of services. It is centered on the relationship that exists between the state and the citizens to a great extent. The theory aimed to bring about economic development, if taxes are paid by the citizens.

\section{Empirical Literature Review}

The study reviewed the following previous studies on the subjection. Ola (2011) taxation has been with man, revenue to the government when taxes paid comes back in the form of social amenities. Data were extracted from major economic indicators. Multiple regression analysis was used to analyse the data and the result revealed that there is positive relationship between capital gains tax and economic development. Onwuchukwu and Aruwa (2014) investigated VAT and economic growth in Nigeria. The study examined the impact of VAT on the economic growth in Nigeria, using different economic indicators. Ordinary least square techniques were used to analyse the data. Results showed that VAT contributed significantly to the total tax revenue of government by extension the economic development of Nigeria.

Beeson et al (2016) examined the determinant of income tax compliance in Mauritius for tax payers. The study adopted primary survey design to obtain data which was analyzed using thematic statistical analysis. Their study revealed that knowledge about tax payment impact significantly on tax compliance and that statutory audit. Personal financial constraints perceptions of government expenditure influences compliance level.

\section{Methodology}

In the course aof this study, descriptive and exploratory research design were employed in determining the cause and effect relationship among the variables in the model. The data was collected from the Central Bank of Nigeria statistical bulletin and records from Federal Inland Revenue Services for the period ranging from 2011 2016 using ordinary least square (OLS) to find the financial relationship between these variables.

\section{Model specification:}

The model formulated for the study expressed the dependent variable as a function of three independent variables, which is expressed below; 
$\mathrm{GDP}=\mathrm{f}(\mathrm{CGT})$

This is expressed mathematically as follows:

$$
\mathrm{GDP}=\beta_{o}+\beta_{1}+C G T+\mu_{\mathrm{o}}
$$

Where: GDP $=$ Gross Domestic Product

CGT $=$ Capital Gains Tax

$$
\begin{array}{lll}
\mu & = & \text { Stoichastic Error Term } \\
\beta_{0} & = & \text { Constants } \\
B_{1} & = & \text { Coefficient of the regression }
\end{array}
$$

\begin{tabular}{|c|c|c|}
\hline Year & CGT & GDP \\
\hline 2011Q1 & 0.05 & 14,501 \\
\hline 2011Q2 & 0.53 & 15,055 \\
\hline $2011 \mathrm{Q} 3$ & 0.95 & 16,164 \\
\hline $2011 \mathrm{Q} 4$ & 0.11 & 17,260 \\
\hline 2012Q1 & 0.57 & 16,450 \\
\hline 2012Q2 & 2.77 & 17,744 \\
\hline 2012Q3 & 4.16 & 18,522 \\
\hline 2012Q4 & 1.40 & 18,998 \\
\hline 2013Q1 & 0.17 & 18,296 \\
\hline 2013Q2 & 16.78 & 19,931 \\
\hline 2013Q3 & 0.14 & 20,464 \\
\hline 2013Q4 & 2.57 & 21,402 \\
\hline 2014Q1 & 0.78 & 20,170 \\
\hline 2014Q2 & 0.29 & 21,735 \\
\hline 2014Q3 & 1.52 & 22,933 \\
\hline 2014Q4 & 0.06 & 24,206 \\
\hline 2015Q1 & 0.25 & 21,042 \\
\hline $2015 \mathrm{Q} 2$ & 10.28 & 22,859 \\
\hline $2015 \mathrm{Q} 3$ & 4.24 & 24,314 \\
\hline 2015Q4 & 0.30 & 25,930 \\
\hline 2016Q1 & 0.19 & 22,235 \\
\hline
\end{tabular}

Table 4.1: GDP and Capital Gains Tax

Source: CBN Banking Statistical Bulletin (2016) www.firs.gov.ng

Table 4.2 Descriptive Statistics

\begin{tabular}{|l|l|l|}
\hline & CGT & GDP \\
\hline Mean & 2.290952 & 20010.05 \\
\hline Median & 0.570000 & 20170.00 \\
\hline Maximum & 16.78000 & 25930.00 \\
\hline Minimum & 0.050000 & 14501.00 \\
\hline Std. Dev. & 4.082380 & 3164.211 \\
\hline Skewness & 2.607213 & -0.005599 \\
\hline Kurtosis & 9.145233 & 2.126290 \\
\hline Jarque-Bera & 56.83487 & 0.668058 \\
\hline Probability & 0.000000 & 0.716033 \\
\hline Sum & 48.11000 & 420211.0 \\
\hline Sum Sq. Dev. & 333.3166 & $2.00 \mathrm{E}+08$ \\
\hline Observations & 21 & 21 \\
\hline Source: Computed $w i t h$ & Eviews &
\end{tabular}

Source: Computed with Eviews 
Table 4.3 Correlational Statistic

\begin{tabular}{|l|l|l|}
\hline & CGT & GDP \\
\hline CGT & 1.000000 & 0.133788 \\
\hline GDP & $0.133788^{\wedge}$ & 1.000000 \\
\hline
\end{tabular}

Source: Computed with Eviews

Table 4.4: Level Series Regression

Dependent Variable: GDP

Method: Least Squares

Date: $08 / 20 / 18$

Time: 05:40 Sample:

2011Q1 2016Q1

Included observations: 21

\begin{tabular}{|c|c|c|c|c|}
\hline Variable & Coefficient & Std. Error & t-Statistic & Prob. \\
\hline $\mathrm{C}$ & 19772.48 & 809.8548 & 24.41485 & 0.0000 \\
\hline CGT & 103.6978 & 176.2192 & 2.588459 & 0.0456 \\
\hline R-squared & 0.517899 & Mean dependent var & & 20010.05 \\
\hline Adjusted R-squared & 0.433790 & & & \\
\hline S.E. of regression & 3217.227 & S.D. dependent var & & 3164.211 \\
\hline Sum squared resid & $1.97 \mathrm{E}+08$ & Akaike info criterion & & 19.08082 \\
\hline Log likelihood & -198.3486 & Schwarz criterion & & 19.18030 \\
\hline F-statistic & 15.346284 & Hannan-Quinn criter. & & 19.10241 \\
\hline Prob(F-statistic) & 0.045635 & Durbin-Watson stat & & 1.260208 \\
\hline
\end{tabular}

Source: Researcher's Computation using E-views

\section{Interpretation of Result}

The result in table 4.4 above shows that the factor in the independent variable $51.8 \%$ determines dependent variable. The F-value of 15.34 also shows that the model has a good fit and that capital gains tax has a very positive and significant relationship with Gross Domestic Product (GDP).

\section{Discussion of Findings}

From the result of the hypothesis tested so far and shown in the table above, the t-value of 2.588 and F-values of 15.35 indicate a rejection of the null hypothesis. The implication is that, capital gains tax has a positive and significant relationship with gross domestic product (GDP). The reason is that capital gains tax provides a source of additional revenue, which enables the government to carry out basic functions of state, hence stimulating economic growth. This finding agrees with the findings of Kwagi and Dabari (2017), which established that capital gains tax has a significant positive relationship with economic growth. Capital gains tax also increases revenue base of government which make fund available for developmental purposes that accelerate economic growth and development. From the analysis, the co-efficient of determination value of $51.8 \%$ is an indication that capital gain tax determines economic growth and development. Thus, capital gain tax revenue affects the overall economic growth and development in Nigeria.

The result of the ordinary least square (OLS) in table 4.3 indicates that capital gains tax has significant ypositive relationship with gross domestic product (GDP) in Nigeria which creates a positive impact on the development of Nigeria economy.

\section{Conclusion}

The study investigated the impact of capital gains tax on the economic development of Nigeria. Secondary data were sourced from the statistical bulletin and online data based on the Central Bank of Nigeria (CBN) and the website of the Federal Inland Revenue service, which was analysed using ordinary least square (OLS) regression method. The findings revealed that income.

It is therefore concludes that capital gains tax has the potential to assist in the diversification of revenue based on Nigerian economy, thereby reducing over dependence on oil revenue as well as developing the economy. Also, other government revenues which include all oil receipts and other receipts into the federation account other than capital gains tax are also found to be positively and statistically related to economic growth and development in Nigeria.

\section{Recommendations}

Based on the findings and conclusion, it is therefore recommended that: Government should state clearly, the basic objective to be derived from capital gains tax system as a means of encouraging tax payers. Besides, it will 
give the tax administrators an idea or direction to educate tax payers on the need to pay tax.

Strict penalty should be meted on people who avoid and evade capital gain tax payment in order to minimize the level of corruption in the administration of capital gain tax and also facilitate the desired impact of capital gain tax on the economy development in Nigeria.

\section{References}

Adeyemi, B.S \& Babington-Ashaye, M.T. (n.d). Introduction of capital Gains tax in the Nigerian Capital Market. Retrieved from http: // www. secure .irs. ogun. org/ downloads / capital_gains_tax_of_stocks_ and shares.pdf

Alabade, J.O, Ariffinb, Z.Z., \& Idris, K.M. (2010). Individual tax payers attitude and compliance behaviour in Nigeria. The moderating role of finance condition and risk performance. Journal of accounting and taxation 6(10), 124-142.

Amatong, D.J. (1975). "Taxation of capital gains in developing country" in reading on taxation in developing countries. Baltimore \& London: the John Hopkins, University press.

Ayua, I.A. (1999). The Nigerian tax law. Ibadan: Spectrum Law Publishing.

FIRS (2009), Guage: A quarterly publication of the federal inland revenue services.

Gatawa, N.M, Aliero, H.M \& Aishata, A.N. (2016). Evaluating the impact of value added tax on the economic development of Nigeria.

Igweike, K.I. (2003). Corporate tax planning and management: An overview issues and legal perspective. 9. UJLJ.

Ola, C.C. (1985). Nigerian income tax law and practice. London: Macmillan publishers.

Olong, A.M. (2006). Tax and taxation issues and procedure of taxpayer/tax authority conflicts under the Nigeria tax laws: An appraisal. Nigerian Bar Journal, 4(2).

Oserogho, E.O. (2004). Legal Alert: Capital Gains Tax and you. Retrieved from http://www.oseroghoassocites.com. Accessed on 25/5/2018

Tripathy, R.N. (1978). Public finance in under-developed countries. World press publishers. 